\title{
THE DIVIDEND POLICY OF COMPANIES LISTED ON THE WARSAW STOCK EXCHANGE
}

\author{
Justyna Bogołębska \\ University of Lodz, Lodz, Poland \\ e-mail: justyna.bogolebska@uni.lodz.pl \\ ORCID: 0000-0002-3730-1849 \\ (C) 2019 Justyna Bogołębska \\ This is an open access article distributed under the Creative Commons Attribution-NonCommercial- \\ -NoDerivs license (http://creativecommons.org/licenses/by-nc-nd/3.0/)
}

DOI: 10.15611/fins.2019.2.02

JEL Classification: G35, G170, G32

\begin{abstract}
Dividend policy is created and formulated by companies. For this reason, the focus of the analysis is on the message conveyed by the information on the dividend payout, the relationship between the dividend and financial indicators, the continuity of the payout and the amount of the dividend itself. Decisions on the dividend payment include two basic issues: what portion of profits should be paid out over a certain period of time and whether the company should maintain a steady and stable growth rate. If a steady and stable growth rate is maintained, then the level of earnings will increase from year to year. This phenomenon is confirmed by the growing number of companies paying dividends. The purpose of the article is to indicate significant differences in stock prices before the dividend payment and after the dividend payment, and to indicate significant differences in stock prices before the announcement of the dividend right and after the announcement of the dividend right.
\end{abstract}

Keywords: dividend policy, share price, investment decision.

\section{Introduction}

F. Miller and M. Modigliani developed the dividend irrelevance theory, according to which dividend policy does not affect the functioning of the company in any way. The bird-in-the-hand theory, defended by M.J. Gordon and J. Lintner, points out that the value of the company will be high if, at the same time, the dividend payout ratio is high. However, the tax preference theory devised by R.H. Litzenberger and $\mathrm{K}$. Ramaswamy, argues that the value of the company will be maximized at a low rate of dividend payout due to the great difference in the tax rates on capital gains and dividends.

The essence of the issue named in the title is the discussion of dividend policy in Polish private limited companies. As a result, dividend policy and its impact on the share price were presented from the perspective of the company. That is why 
the focus of the analyses is on the conveyed message about the paid dividend, the relationship between the dividend and financial indicators, the continuity in its payout and the amount of the dividend itself.

Decisions on paying dividends include two basic issues: what portion of profits should be paid out at a specific time and whether the company should maintain a steady, stable growth rate. If a steady and stable growth rate is maintained, then the level of earnings will increase from year to year. This translates directly into the possibility of sharing profits with the shareholders. The growing Polish stock market indicates an increase in the interest of the dividend policy as such by companies. This phenomenon is confirmed by the growing number of companies paying dividends. The purpose of the article is to indicate statistically significant differences in stock prices before the dividend payment and after the dividend payment, and to indicate significant differences in share prices before the announcement of the dividend right and after the announcement of the dividend right. The adopted time horizon is shortterm - seven days before the specified event (the dividend payment date and the date of the announcement of the dividend right) and seven days after the specified event (the dividend payment date and the date of the announcement of the dividend right). On this basis two research hypotheses were presented:

H1: There are statistically significant differences between share prices before the date of the announcement of the dividend right and after the date of the announcement of the dividend right.

H2: There are statistically significant differences between share prices before the dividend payment date and after the dividend payment date.

\section{The research methodology and the course of the research process}

According to the source literature, most of the financial time series do not meet the assumption about the normality of distribution, which influences the conclusions drawn from the methods used to support investment decisions [Tarczyński, Witkowska, Kompa 2013, p. 34]. In consequence this may contribute to a decrease in investment effectiveness. Information on the stock prices of companies paying dividends at least twice in the whole research time period were collected. The time horizon was 2000-2011. The time horizon for testing the statistical significance of prices before paying the dividend and after paying the dividend was 7 days. The time horizon of the collected share prices for the date of the dividend right was determined in an analogous way -7 days before the announcement of the dividend right and 7 days after the announcement of the dividend right. Therefore, nonparametric tests were used because data verification by means of the Lillefors test showed that the data did not have a normal distribution. The difference between the closing prices - the minimum, maximum and average - was checked statistically by means of the Kruskal-Wallis test. The chronological average was used to describe the differences 
between the closing price before the payment of the dividend and the closing price after the payment of the dividend. Checking the differences between the chronological averages was carriedout on the basis of the Mann-Whitney U test. The differences between the chronological averages before the dividend payment and after the dividend payment were described by means of the nonparametric Wilcoxon test.

A targeted selection of listed companies was used for the entire database. The analysis of the information from the available databases of the Warsaw Stock Exchange and the Notoria database regarding the date of the dividend right and the dividend payment date was helpful in selecting the appropriate companies for the audit. Each of the companies had to meet two conditions - they had to be listed on the Warsaw Stock Exchange and to pay dividends to their shareholders at least twice. A one-time dividend payment indicates the randomness of this event and has no impact on the undertaken research. On this basis a database was created to which the information on the share prices in the audited period was attached. The database consisted of 248 companies which paid dividends to their shareholders at least twice between 2001 and 2011. The database created on the basis of the adopted assumptions had over 15,000 observations.

\section{The functions and importance of dividends in economic practice}

The dividend is most often the source of a company's profit from the previous year. The taxation of dividends and the costs of their payment incurred by the company in the event of their payment to the shareholders and their recognition by the shareholders were described in the source literature as the dividend puzzle [Zielonka 2003, p. 113]. This is due to the fact that despite the double taxation of dividends, investors are still interested in receiving them, while companies are interested in paying them. The importance of dividend policy in listed companies is increasing, as there is an increasing number of companies which pay dividends to their shareholders. It is also an undeniable fact that carrying out a dividend policy in joint-stock companies and sharing profits with shareholders is an important aspect of the substantive and practical discussions of modern finance. For shareholders the dividend is the information on the level of return on the previously invested capital. This is due to the fact that on the basis of the dividend policy pursued by companies, shareholders may make decisions on a possible investment in the company's securities or not [Szablewski 2006, pp. 287-312].

Dividend policy in joint-stock companies should therefore be considered on the basis of the functions which it fulfils in economic practice [Poterba 1987, pp. 455-515; Lewandowski 2010, p. 69]:

- the information function,

- the income-cost function, 
- the control function,

- the motivation function.

The information function of the dividend consists in the signal of the dividend payout for a given financial year being treated as information for the shareholders on the company's current condition. A shareholder, who is assumed not to have all the information about the company, may treat the above information as a forecast. Depending on the situation of the company on the market, the above forecast can be considered negative or positive. In most cases the information about dividend payment is treated as positive. This happens because this information is interpreted as the good financial condition of the company and a possible increase in its profits in the future. In the source literature the information function of the dividend was confirmed in the studies by J. Lintner and S. Bhattacharya [Lintner 1956, pp. 97-113]. It was proven that managers attach more importance to the change of the dividend amount, and it was also shown that managers are not inclined to change the level of paid dividends if in the future they are forced to reduce the level previously declared. The survey, conducted in 2005, covered 384 companies. The income-cost function of the dividend is understood as exercising property rights by the shareholders. The shareholders who prefer dividend-paying companies in their investment choices have been paying close attention to the certainty of its payment recently. A far more reliable security is a certain amount of the dividend. This is due to the fact that shareholders prefer to receive a certain amount of the dividend, which in most cases is known. The received dividend is regarded by the shareholders as a certain source of return on the previously invested capital. In addition, the researchers [Gordon, Shapiro 1956, pp. 102-110] also suggested that the dividend be paid out of the total profit achieved by the company. The control function of the dividend is closely related to the concept of agency costs in the company. "The agency theory draws attention to the contractual relationships between shareholders and managers and the problem of maximizing the usefulness of both groups. Shareholders, who are principals, delegate to managers many decisions which, owing to their ownership, should be their domain. Then the managers become their agents. Agents also strive to maximize their own usefulness, and thus they do not always work as expected by the principals. It is easier for managers to maximize their own usefulness because they know more about the planned strategies of the companies, their operations and the sources of financial results than shareholders, who are forced to trust them" [Bohdanowicz 2012, pp. 54-68]. In such relationships the dividend has remained a financial instrument for controlling the financial situation within the company [Pioch 2004, p. 475]. The use of the dividend as a financial instrument consists in the systematic payment of the dividend to shareholders. A positive effect is the use of cash for further investment purposes. The prospect of receiving dividends over a long period of time causes shareholders to be able to be willing to commit to the company for the long term. The choice of the company which pays a dividend is determined by the amount and frequency of the received dividend [Dębski 2007, p. 210]. A company which grows 
and regularly brings more profits will be able to pay much bigger dividends to its shareholders in the future. The payment of small dividends by shareholders at the beginning of the company's existence does not pose any problem for the stakeholders concerned. When the situation is reversed, i.e. companies immediately pay high dividends and then they want to reduce their level, this may be badly received by investors. The decision to reduce dividends may be received by shareholders in a negative way, as it can be read as a signal of impending problems in the enterprise. Any planned change in the adopted dividend policy should be clarified and justified before the shareholders. The implementation of dividend policy in companies is an important matter. This is particularly relevant at the time when dividend policy is formulated by the company's management. Dividend policy should be tailored to the specific characteristics of a given company, as it has a significant impact on the company's operations and it can indirectly influence the company's image among the shareholders themselves.

\section{The empirical study of dividend policy under the conditions of the Polish capital market}

The main objective was verified by using nonparametric tests, which determined the level of significantly statistical differences between share prices before the announcement of the dividend right and after the announcement of the dividend right. Exactly the same methodology was applied in the case of the dividend payment statistically significant differences between share prices a week before the dividend payment and a week after the dividend payment were examined. A short observation period of the changing stock price allows eliminating other factors which affect the price of the shares themselves. The first stage of the study was the application of the formula below:

$$
\bar{x}=\sum_{i=1}^{n} \frac{1}{2}\left(\frac{y_{1}-y_{2}}{y_{1}+y_{2}}\right) \cdot 100 \%,
$$

where: $y_{1}$ - first observation in a series prior to the date of the announcement of the dividend right/the date of the dividend payment to the shareholders, $y_{2}-$ first observation in a series after the date of announcement of the dividend right/ the date of the dividend payment to shareholders, $\bar{x}$ - average calculated from two periods.

This is the quotient of the rates of return divided by the chronological average. In this manner it is possible to compare the prices of all stock rates by reducing them to a common value. The purpose of using the above calculation formula was to reduce all stock price values, expressed in zlotys, to one synthetic measure of value.

On the basis of the closing share prices, the share prices were compared before the dividend right was announced ( 7 days before) and after the dividend right was 


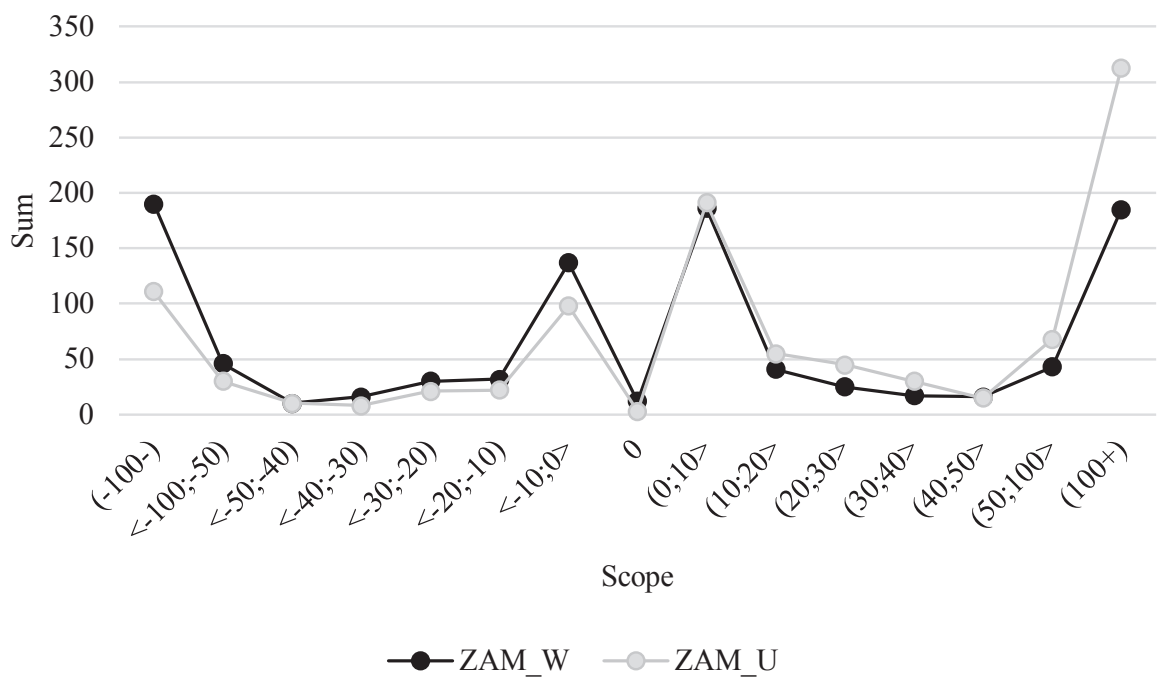

Fig. 1. Comparison between closing prices for the date of the dividend payment (ZAM_W) and closing prices for the date of determining the dividend right (ZAM_U)

Source: own elaboration.

announced ( 7 days after), as well as the closing prices before the dividend payment date (7 days before) and after the dividend payment date ( 7 days after). Among all mean observations ( $Y$-axis), the largest percentage changes $(X$-axis) can be seen in the range of $0 \%$ to $10 \%$. Therefore, it should be pointed out that the closing prices in two cases - the announcement of the dividend right and the payment of the dividend - changed in two ranges of $-10 \%$ to $0 \%$ and $0 \%$ to $10 \%$. Given the number of observations (over 15,000), it seems that the change in share prices in a given range results from a specific dividend policy. Statistical verification was also carried out to examine the hypothesis that the dividend policy affects the share price. The chronological average was used to determine the average level of the phenomenon observed at different moments in time [Starzyńska 2002, pp. 96-98]. In addition, the calculation was made for the closing prices before paying the dividend and for the closing prices after paying the dividend. In this manner, 953 observations of chronological averages before the receipt of the dividend were obtained for closing prices and the same number of observations for chronological averages after the date of receiving the dividend was also obtained. The selection of the appropriate statistical test requires, in the first instance, checking whether the calculated chronological averages have a normal distribution [Tarczyński, Witkowska, Kompa 2013, p. 19]. None of the time series had the normal distribution, therefore nonparametric tests were taken into account. In the next stage of the study the difference between the chronological averages was calculated. Thus, the Wilcoxon test was carried out in 
order to check a statistically significant difference between the chronological average before the dividend payment and the chronological average after the dividend payment.

H0: The median for the difference in chronological averages before and after the companies' dividends are paid is 1 .

H1: The median for the difference in chronological averages before and after the companies' dividends are paid is different from 1.

Table 1. The Wilcoxon test for the difference between the chronological average before and after the dividend payment to shareholders

\begin{tabular}{|c|c|}
\hline \multicolumn{2}{|c|}{ Wilcoxon test (signed-rank test) } \\
\hline Analysed variables & Difference \\
\hline Significance level & 0.05 \\
\hline Correction for continuity & Yes \\
\hline Cardinality - group & 963 \\
\hline Cardinality of omitted values (equal to the median) & 0 \\
\hline Median of the studied group & -0.02875 \\
\hline Hypothetical median & 1 \\
\hline Sum of positive ranks & 107406 \\
\hline Sum of negative ranks & 356760 \\
\hline$T$-statistics & 107406 \\
\hline$p$-value (exact) & 0.0001 \\
\hline Z-statistics (includes correction for tied ranks) & 14.441017 \\
\hline$p$-value (asymptotic) & $<0.000001$ \\
\hline
\end{tabular}

Source: own elaboration.

Comparing the $p$-value of the Wilcoxon test based on the $T$-statistics with a given significance level, it should be stated that there are statistically significant differences as a result of subtracting the chronological averages after paying the dividend from the chronological averages before paying the dividend. The same decision should be made on the basis of the $p$-value of the Wilcoxon test based on the $Z$-statistics, which includes a correction for tied ranks. The difference between the averages is not great, but it can be seen that the sum of the negative ranks is greater, so it should be assumed that there exists the influence of the dividend on the share price of a company and that it is negative. The descriptive statistics of the differences were a conducive condition for checking the differences between the chronological averages before the dividend payment and after the dividend payment for the closing prices. In the last stage of the study the Kruskal-Wallis test was used. The one-factor analysis of variance for the Kruskal-Wallis ranks is an extension of the Mann-Whitney $U$ test for more than two populations. This test serves to verify 
the hypotheses on the insignificance of the differences between the medians of the studied variable in several populations, on the assumption that the distributions of variables are close to each other. Therefore, the following statistical hypotheses were made:

H0: The medians of particular averages for closing prices, the minimum, maximum and average ones are equal.

H1: The medians of particular averages for closing prices, the minimum, maximum and average ones are different.

Table 2. ANOVA Kruskal-Wallis test

\begin{tabular}{|l|l|l|}
\hline Analysed variables & Average opening rate & Average maximum rate \\
Significance level & 0.05 & Average minimum rate \\
\hline Degrees of freedom & 3 & Average closing rate \\
\hline$H$-statistic (includes correction for tied ranks) & 15.482034 & \\
\hline$p$-value & \multicolumn{2}{|c|}{0.001448} \\
\hline
\end{tabular}

Source: own elaboration

The resulting p-value shows a significant difference between the medians for the closing stock prices, the minimum, maximum and average. Accordingly, it should be assumed that the paid dividend results in significant differences of the stock prices -7 days before the announcement of the dividend right and 7 days after the announcement of the dividend right. This is also confirmed by the particular values in the descriptive statistics for the average closing stock prices, the minimum, maximum and average. According to the information in the previous chapter, the volume of stock price fluctuations is at $10 \%$.

\section{The analysis of the causes of changes in the share prices of listed companies}

The development of the stock exchange resulted in the emergence of new companies and the increase in competition between them. As a result, the acquisition of capital directly from the stock exchange required companies to formulate transparent statements addressed to shareholders. The increased number of dividends paid from year to year is a message that should be interpreted as information about the good financial condition of a company. Further research shows an increase in the regularity of the paid dividends and an increase in the level of paid dividends. However, this situation has only been taking place since 2008. It can be assumed that the adopted research period for the assessment of the dividend policy is the period in which the development of the capital market occurred. In comparison with 
the US market, where dividends are paid much more frequently, the Polish market is just at the beginning of this road. The emergence of the WIGdiv index should be considered a breakthrough and an important moment in terms of paying dividends to shareholders. It was shown in the conducted study that, under the influence of the paid dividend, the benchmark for the quotations of the companies' shares is at $0-10 \%$. The analysis of the last decade lets us think that the pursuit of dividend policy is increasingly seen by companies as an important element of a company's strategy. It is also interesting that the conducted research showed that companies have been regularly paying dividends since 2008 , which was also the first period of the economic crisis. It seems that during the economic crisis, companies adopted the dividend payment strategy as a marketing element, which according to the signaling theory indicated a positive reception of such companies by the market. In the long term, this reflected the good financial situation of the company. The applied statistical tests showed the existence of statistically significant differences in stock prices 7 days before the announcement of the dividend right and 7 days after the announcement of the dividend right. The analogous results of the applied nonparametric tests were obtained by examining statistically significant differences in stock prices 7 days before the dividend payment date and 7 days after the dividend payment date [Rudke 2015].

The dividend for shareholders as remuneration for the capital entrusted to companies is certainly an attractive and quite predictable instrument to shareholders, especially if we take into account the long-term perspective for investors who buy shares of a given company. The companies which were studied in the survey paid the dividend in a rather regular and predictable manner. This trend can be seen if we are talking about companies which paid the dividend more than four times over the analysed period. In addition, in comparison to other instruments offered by the stock exchange, the dividend is also attractive in terms of finance. The pioneers of paying dividends to shareholders are definitely energy companies and banks. They paid a higher dividend than average for the entire group for the time period under consideration [Rudke 2015]. Shareholders who receive a stable and predictable dividend perceive the company significantly better, and are also far more willing to entrust their capital to it. A clear growing trend can be seen when it comes to the investors' interest in companies which pay the dividend. It also turns out that the companies themselves are sharing their profits with shareholders in an increasingly efficient and predictable way. However, compared to the US market, the companies have been showing an interest in paying dividends only over the last few years. The appearance of the WIGdiv index on the Warsaw Stock Exchange can be symbolically taken as the beginning of this period. The conducted research showed that dividend policy can have a statistically significant impact on the company's share price, which simultaneously makes a significant contribution to the theory of dividend policy and gives an important voice in the field of current research. The obtained results and the presented conclusions seem to be the closest to the Gordon-Lintner theory. 
The interpretation of specific results calculated on the basis of the time series is limited. This happens because the stock price of a given company changes under the influence of many factors. The following factors should be regarded as the most important: the benefits which shareholders receive, the degree of trust on the part of shareholders, as well as the assessments regarding the development of the overall economic situation [Bień 2004, p. 154]. There are also macroeconomic factors which influence the stock price, which concern the political and economic situation in the country. Additionally, in the macroeconomic factors the occurrence of inflationary phenomena is mentioned. The increase in the prices of generally available basic consumer goods may affect the limitation of cash resources allocated for investments, thus reducing the willingness to invest. An important macroeconomic factor is also a change of the market conditions in the country and abroad. This has been especially visible this year when there was a risk of Greece leaving the Eurozone. The domestic stock markets reacted by changing and decreasing the demand for shares in the short-term period. This resulted from the emergence of the risk of weakening the Eurozone and the need to allocate high amounts in order to improve the condition of the Greek budget. In an indirect way, the negative perception of the Eurozone and its individual members may also weaken the willingness of individual investors to invest on the domestic stock exchange. An important macroeconomic aspect which can shape the demand for shares is the policy adopted by banks. In connection with the problems related to loans in foreign currencies and the growing exchange rate of the Swiss currency, there is a risk of insolvency of people who have such loans. This type of risk may significantly affect the financial liquidity of banks. In connection with this, the issued recommendations regarding the payment of dividends to shareholders by banks had to be adjusted. "This is because banks are subject to the supervision of the PFSA, which issues recommendations (in practice they are conditions) which they must meet to be able to pay dividends at all. This is mainly about the core capital ratio (Core Tier 1 ratio) and the more important one the total capital ratio (Capital Adequacy Ratio). If banks have the appropriate values of these ratios, they can pay up to $100 \%$ of the dividend. If they have the average values, they can only pay $50 \%$ of the dividend. However, if they have too low values, in line with PFSA's recommendations they should not pay dividends at all. To make things more difficult, the banks with a significant deposit market share of the nonfinancial sector must have higher solvency ratios than the banks with no significant share in this market" [Kwestarz 2015]. Apart from the abovementioned factors, there are also microeconomic factors: changes of the organizational structures, the company's failure to pursue technological development, the increased number of enterprises of the same or similar company profile, the non-optimal asset structure, and wrong decisions taken by the board in connection with the management of a given enterprise.

The aforementioned macroeconomic and microeconomic factors do not exhaust the entire catalogue of factors which have an indirect or direct impact on the share 
price. The behavioural factor concerning the conduct of individual investors is definitely the least measurable.

\section{Bibliography}

Bień W., 2004, Rynek papierów wartościowych, Difin, Warszawa.

Bohdanowicz L., 2012, Funkcja kontrolna rady nadzorczej a redukcja kosztów agencji, Zarządzanie i Finanse, Wydawnictwo Uniwersytetu Gdańskiego.

Dębski W., 2007, Rynek finansowy i jego mechanizmy. Podstawy teorii i praktyki, Wydawnictwo Naukowe PWN, Warszawa.

Gordon M.J., Shapiro E., 1956, Capital equipment analysis: the required rate of return of profit, Management Science, no. 3.

Kwestarz P., Powód spadków sektora bankowego po kryzysie franka szwajcarskiego (dywidendy, zyski i $K N F$, https://strefainwestorow.pl/artykuly/dywidendy/powod-spadkow-sektora-bankowegopokryzysie-franka-szwajcarskiego-dywidendy-zyski (15.05.2015).

Lewandowski R., 2010, Polityka dywidend w spółkach akcyjnych na Giełdzie Papierów Wartościowych $w$ Warszawie, doctoral dissertation, Toruń.

Lintner J., 1956, Distribution of incomes of corporations among dividends, retained earnings, and taxes, American Economic Review, no. 46(2).

Pioch J., 2004, Polityka dywidend w teorii i praktyce, [in:] Dziawgo D. (ed.), Indywidualni inwestorzy na rynku finansowym, Wydawnictwo Uniwersytetu Mikołaja Kopernika, Toruń.

Poterba J., 1987, Tax policy and corporate saving, Brookings Papers on Economic Activity, no. 2

Rudke M., Duże dywidendy w dużch spótkach, wydanie internetowe Gazety Parkiet, access online 14.05.2018.

Starzyńska W., 2002, Miary średnie w szeregach czasowych. Statystyka praktyczna, PWN, Warszawa.

Szablewski A., 2006, Wycena spótki metodą zdyskontowanych dywidend, [in:] Panfil M., Szablewski A. (ed.), Metody wyceny spótki. Perspektywa klienta i inwestora, Poltext, Warszawa.

Tarczyński W., Witkowska D., Kompa K., 2013, Wspótczynnik Beta. Teoria i praktyka, Pielaszek Reaserch, Warszawa.

Zielonka P., 2003, Czym sa finanse behawioralne, czyli krótkie wprowadzenie do psychologii rynków finansowych, Materiały i Studia Narodowego Banku Polskiego, zeszyt nr 158.

\section{POLITYKA DYWIDENDOWA FIRM NOTOWANYCH NA WARSZAWSKIEJ GIELDZIE PAPIERÓW WARTOŚCIOWYCH}

Streszczenie: Polityka dywidendowa jest tworzona i formułowana przez firmy. $Z$ tego powodu analiza skupia się na przesłaniu informacji o wypłacie dywidendy, relacji między wskaźnikami dywidendy i finansowymi, ciągłości wypłaty i wysokości samej dywidendy. Decyzje o wypłacie dywidendy obejmują dwie podstawowe kwestie: jaka część zysków powinna zostać wypłacona w pewnym okresie oraz czy spółka powinna utrzymywać stałą i stabilną stopę wzrostu. Jeśli utrzyma się stabilna i stała stopa wzrostu, poziom zarobków będzie wzrastał z roku na rok. Zjawisko to potwierdza rosnąca liczba spółek wypłacających dywidendy. Celem artykułu jest wskazanie znacznych różnic w cenach akcji przed wypłatą dywidendy i po jej wypłacie oraz znacznych różnic w cenach akcji przed ogłoszeniem prawa do dywidendy i po jego ogłoszeniu.

Słowa kluczowe: polityka dywidendowa, cena akcji, decyzja inwestycyjna. 